\title{
Protein Stabilization
}

\author{
Vishard Ragoonanan Alptekin Aksan
}

Biostabilization Laboratory, Department of Mechanical Engineering, Institute of Technology, University of Minnesota, Minneapolis, MN, USA

\section{Key Words}

Protein stability · Biostabilization · Biothermodynamics

\section{Summary}

The need for efficient and safe stabilization procedures for biomaterials, therapeutic proteins, and cells is increasing with advances in medicine and pharmaceutics. Stabilization of a protein translates into preservation of the protein structure during storage, in thermodynamic equilibrium with its surroundings. Here, we present a review of the basic thermodynamic principles that govern the protein structural transitions and the interactions of the protein with its surroundings. Specifically, the roles of pressure, temperature, solvent mobility, and solute concentration are discussed. Various methods that can be used to measure protein structure and function, and also the currently available stabilization methods are reviewed. We also introduce a new and promising stabilization method, nanoencapsulation. Similar to the stabilization mechanism of osmolytes, in nanoencapsulation the water activity is altered, affecting the molecular motions of the proteins. There are several distinct advantages of nanoencapsulation, which may also open the way to successful stabilization of biomaterials for bioreactive coatings, biosensors, and biocatalysts.

\section{Schlüsselwörter \\ Proteinstabilität · Biostabilisierung · Biothermodynamik}

\section{Zusammenfassung}

Der Bedarf an effizienten und sicheren Stabilisierungsmöglichkeiten für Biomaterialien, therapeutisch eingesetzte Proteine und Zellen nimmt mit den Fortschritten in der Medizin und in der Pharmazie beständig zu. Die Stabilisierung eines Proteins wird durch die Konservierung der Proteinstruktur während der Lagerung erreicht, durch thermodynamisches Gleichgewicht mit der Umgebung. In dieser Übersichtsarbeit stellen wir einerseits die grundlegenden thermodynamischen Prinzipien vor, die eine Veränderung der Proteinstruktur regulieren sowie andererseits die Interaktionen des Proteins mit seiner Umgebung. Insbesondere werden die Rolle von Druck, Temperatur, Beweglichkeit des Lösungsmittels und Konzentration des gelösten Stoffs diskutiert. Auf verschiedene Methoden, mit denen die Proteinstruktur und -funktion gemessen werden kann, sowie auf derzeit verfügbare Stabilisierungsmöglichkeiten wird ebenso eingegangen. Darüber hinaus wird eine neue und vielversprechende Stabilisierungsmethode, die "Nanoverkapselung», vorgestellt. Ähnlich wie beim Stabilisierungsmechanismus, wie er mit osmotisch aktiven gelösten Stoffen erreicht werden kann, ist bei der «Nanoverkapselung" die Wasseraktivität in den Poren verändert, wodurch sich die Molekularbewegungen der Proteine verändern. Es gibt einige besondere Vorteile der «Nanoverkapselung", die dazu beitragen können, den Weg für die erfolgreiche Stabilisierung von Biomaterialien für Beschichtungen, Biosensoren und Biokatalysatoren zu bereiten.

\begin{tabular}{ll}
\hline KARGER & @ 2007 S. Karger GmbH, Freiburg \\
$\begin{array}{l}\text { Fax +49 76145207 14 } \\
\begin{array}{l}\text { E-mail Information@Karger.de } \\
\text { www.karger.com }\end{array}\end{array}$ & $\begin{array}{l}\text { Accessible online at: } \\
\text { www.karger.com/tmh }\end{array}$ \\
\end{tabular}

Vishard Ragoonanan

Biostabilization Laboratory, Department of Mechanical Engineering

Institute of Technology, University of Minnesota

111 Church Street SE, Minneapolis, MN 55455, USA

Tel. +1 612 626-8111, Fax -6069

E-mail vishardr@me.umn.edu 


\section{Introduction}

Stabilization and storage of susceptible biological organisms, and materials is of increasing importance. Over the years, different stabilization protocols as well as preservation and storage methods have been developed for cells, bacteria, proteins, whole blood, and blood products. Advances in biostabilization techniques may result in storage of platelets and red blood cells [1] by freeze drying. Further improvement of the existing methods to match the increasing demand of the medical technologies requires basic understanding of the interactions of the biological material with its environment. In this manuscript, we focus on the stabilization methods available and the basic mechanisms involved. Although we primarily focus on the stabilization of proteins, the principles discussed are applicable to all biological systems and organisms.

With the advances in medicine, the demand for successful stabilization of therapeutic proteins is increasing. Starting with the production of the first therapeutic antibody for the treatment of B-cell non-Hodgkin's lymphoma in 1997, therapeutic protein production has been growing steadily. It reached to such an extent that as of 2006 there are approximately 500 products that have been either approved or are awaiting approval by the FDA in the USA. Insulin, plasma proteins, enzymes, collagen, fibrinogen, coagulation factors, monoclonal antibodies, and interferons are produced synthetically, by cloned transgenic animals, microbial fermentation or mammalian cell culture. In fact, monoclonal antibodies form the second largest biopharmaceutical product category in clinical trials at present [2]. Complex production processes and high production costs associated with these complex proteins require that they are successfully stabilized, and preserved at high efficiency for long periods of time.

Protein stabilization is based on dampening the molecular motions and therefore eliminating conformational transitions while the protein is still in the native state (i.e. has native, folded structure). The structure of a protein is dictated by the intramolecular interactions and its interactions with the surrounding solutes and solvents. These interactions consist of ionic bonds, hydrogen bonds, polar and Van der Waals interactions. The effect of the solvent on the protein is primarily through hydrogen bonding and the polar interactions. Most non-specific effects of solutes on the molecular motions of proteins are hypothesized to be indirect: through modification of the molecular motions and the chemical, physical and thermodynamic properties of the solvent.

Water has unique properties and is the universal solvent governing the molecular motions, structures and therefore the functions of proteins (see [3] for a recent review on the role of water in biostabilization). Therefore, irrespective of the particular stabilization method utilized (cooling, freezing, drying or a combination of these processes), dampening the molecular motions of the protein to be preserved is achieved by reducing the chemical activity of the surrounding water by ei- ther changing its thermodynamic phase, exposing it to solutes that alter its chemical activity, or by removing it completely. For example, stabilization of the therapeutic protein recombinant human factor XIII by freeze drying [4] involves the replacement of water by stabilizing solutes such as trehalose. Stabilization mechanisms for preservation of cells and bacteria are also based on modifying surrounding water. This is taken into consideration in experiments to stabilize platelets by freeze drying which involves steps to stabilize the membrane by replacing the water molecules near the membrane lipid headgroups with the disaccharide trehalose [5].

Stabilization methods aim at preserving the function of a protein by stabilizing its structure during storage. Protein structure is quantified at three different levels: primary, secondary and tertiary. The primary structure consists of the specific sequence of the amino acids that make up the protein. The primary structure typically remains unaltered during the preservation processes since the peptide bonds that bind the amino acids are quite strong and are not easily broken by the changes in hydration or temperature. The secondary structure is the three-dimensional structure assumed by certain domains in the protein. These local structures are mainly determined by the hydrogen bonding within the peptide backbone. The two most common structures in protein domains are the $\alpha$ helix and the $\beta$-sheet. Denaturation and aggregation of proteins, observed during preservation processes or storage, are commonly associated with the alterations in the populations of the $\alpha$-helix, $\beta$-sheet, and random coil structures. The tertiary structure of a protein is its three-dimensional folded shape, where generally the hydrophobic side-groups are hidden in the core and the hydrophilic groups are exposed to the surrounding solvent. Ultimately, it is the tertiary structure of the protein that determines its function. Both the primary and secondary structures of a protein contribute to its tertiary structure. Changes in the physical, chemical and thermodynamic properties in the microenvironment affect the secondary and the tertiary structure of the protein causing it to change its conformation, unfold (denature), and lose its function [6].

\section{Thermodynamics of Stabilization}

At the molecular level, there are many different conformations that a protein may adopt. The transition between these conformations is determined thermodynamically by the difference in the Gibbs free energy levels $(\Delta \mathrm{G})$, between the two different states, which fall into a complex energy landscape.

$$
\Delta \mathrm{G}=\mathrm{G}_{\mathrm{d}}-\mathrm{G}_{\mathrm{n}}=\Delta \mathrm{H}-\mathrm{T} \Delta \mathrm{S}
$$

The equation given above expresses the difference in the Gibbs free energy levels between two configurations $(\Delta G)$ as a function of the transition enthalpy $(\Delta \mathrm{H})$ and transition en- 


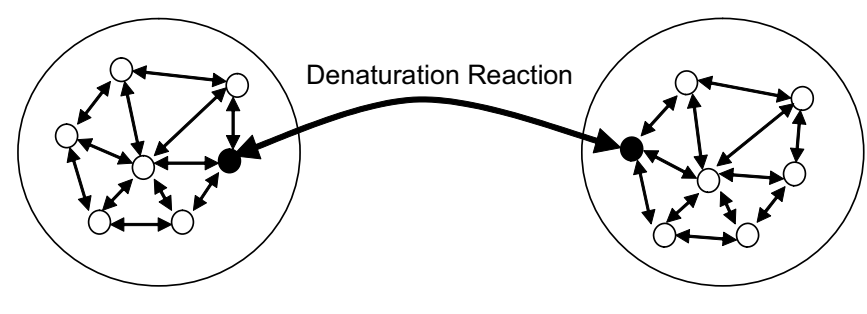

Native MacroState

Denatured MacroState

Microstate

Gatestate

Fig. 1. Dynamics of protein denaturation. Adapted from [7].

tropy $(\Delta S)$, where $\left(G_{d}\right)$ is the Gibbs free energy of the protein in the unfolded (denatured) state, $\left(G_{n}\right)$ is the Gibbs free energy in the folded (native) state, and (T) is the absolute temperature. If $\Delta \mathrm{G}$ is negative, seeking the lowest energy state, the protein would transition from its native state and denature. At the denatured configuration, the protein cannot perform its function. This expression naturally assumes that the native and the denatured states are unique states corresponding to unique confirmations of the protein. However, it has been shown that a protein can assume slightly different configurations in the native as well as in the denatured state. These microstates are accessible to the protein stochastically, however, the transition between the two macrostates are only possible through certain gate states. The gate states correspond to the 'transition' states where the protein is more likely to transition from one macrostate to another (fig. 1).

The enthalpy of denaturation and the entropic contribution are significantly larger than the change in the Gibbs free energy and, therefore, the protein can transition spontaneously from a native to a denatured state with a slight shift in the entropic/enthalpic balance [8]. Any factor that can alter the free energy difference between the two states will affect the stability of the protein. Since the equilibrium of a protein in any state is dictated by the entropic and enthalpic factors, it would be wrong to think that denaturation is only achieved by an increase in temperature. Stability theories predict that proteins can denature not only by increasing the temperature but also by decreasing it (cold denaturation). Figure 2 presents the elliptical stability region predicted by the Hawley theory, which shows all of the thermodynamically possible denaturation processes starting from an initial state (shown by the solid circle in the shaded, native area). As predicted by the theory, $\mathrm{T}_{\mathrm{H}}$, and $\mathrm{T}_{\mathrm{L}}$ correspond to high and low denaturation temperatures, while $\mathrm{P}_{\mathrm{H}}$ and $\mathrm{P}_{\mathrm{L}}$ correspond to high and low denaturation pressures, showing that it is also possible to denature a protein isothermally by changing the pressure.

As explained above (fig. 1), native and denatured states are not unique states, but are composed of a subset of microstates among which the protein continuously transitions through vi-

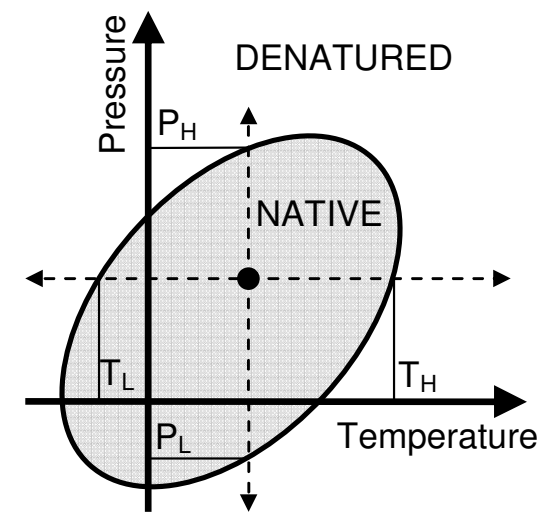

brations of its backbone or the side-chains. However, this should not be confused with the relaxational configurational motions between the gate states. Based on this argument, molecular stability can also be analyzed from a kinetic perspective by examining the changes in the relaxational time constants between two available configurations (i.e. the time it takes for the protein to change its configuration between the native and the denatured states). Hence, stability is related to the molecular relaxation time which is a function of the configurational entropy [9]. Configurational entropy, on the other hand, is a strong function of the number of available microstates (degeneracy) in any macrostate. If a large number of microstates exist, there will be large configurational entropy, a correspondingly short relaxation time, and high molecular mobility. Zhou et al. [9] showed that molecular mobility directly determines the storage stability of amorphous pharmaceuticals. Therefore, there is a direct link between the molecular motions of the protein and the molecular motions of its surroundings, and stabilization can be established by dampening the motions of the surroundings (such as by increasing its rotational, translational, and vibrational viscosity).

From a broader perspective, the chemical and physical transitions that a protein undergoes changing from its native state to the unfolded state may result in aggregation, crystallization, degradation, and denaturation. Due to the protein's constant exploration of the configurational landscape and its interactions with the solvent and the surrounding solutes, it can adopt configurations that favor intermolecular interactions [10]. This may result in formation of hydrophobic interactions among proteins, called aggregation, which becomes more of an issue in low molecular mobility environments where the solvent chemical activity also decreases [11]. Alternatively, the protein may also become insoluble or crystallize. Protein degradation involves biochemical processes that change the protein chemically. A detailed review of protein degradation can be found in Manning et al. [11]. The extent to which molecular mobility influences protein degradation is not yet fully understood, but it has been suggested that the coupling of the degradation rate limiting step with structural relaxation may be the 
Table 1. Experimental methods to determine protein structure and stability [37-39]

\begin{tabular}{|c|c|c|}
\hline Method & Advantages & Disadvantages \\
\hline Fourier transform infrared spectroscopy (FTIR) & $\begin{array}{l}\text { simple sample preparation, small sample size, } \\
\text { liquid or solid samples can be examined, } \\
\text { information about protein secondary structure } \\
\text { is available, rapid data acquisition is possible, } \\
\text { non-invasive }\end{array}$ & $\begin{array}{l}\text { does not give information on tertiary } \\
\text { structure, water frequently obscures protein } \\
\text { vibrations, extensive data processing is } \\
\text { required to identify specific features } \\
\text { (spectral deconvolution or statistical } \\
\text { comparison to other known proteins) }\end{array}$ \\
\hline Raman spectroscopy & $\begin{array}{l}\text { simple sample preparation, small sample size, } \\
\text { liquid or solid samples can be examined, } \\
\text { information about protein secondary structure } \\
\text { is available, rapid data acquisition is possible } \\
\text { (FT-Raman), non-invasive, water bands do not } \\
\text { complicate analysis }\end{array}$ & $\begin{array}{l}\text { does not give information on tertiary } \\
\text { structure, sensitive to fluorescence artifacts, } \\
\text { sample may degrade due to intense laser } \\
\text { excitation, extensive data processing is } \\
\text { required to identify specific features }\end{array}$ \\
\hline Circular dichroism (CD) & $\begin{array}{l}\text { simple sample preparation, small sample size, } \\
\text { sample in solution form, information on } \\
\text { secondary structure is available }\end{array}$ & $\begin{array}{l}\text { does not give information on tertiary } \\
\text { structure, kinetic processes cannot be } \\
\text { monitored easily }\end{array}$ \\
\hline Nuclear magnetic resonance (NMR) & $\begin{array}{l}\text { detailed structural information, liquid or solid } \\
\text { samples can be examined, can be used to } \\
\text { investigate protein dynamics }\end{array}$ & $\begin{array}{l}\text { long data collection time, extensive data } \\
\text { processing, limited to small proteins }\end{array}$ \\
\hline X-Ray crystallography & detailed structural information available & $\begin{array}{l}\text { requires single crystal samples (not always } \\
\text { feasible), extensive data processing }\end{array}$ \\
\hline Fluorescence-based activity assays & $\begin{array}{l}\text { supplies direct information on protein } \\
\text { functionality and activity }\end{array}$ & very limited structural information available \\
\hline Differential scanning calorimetry (DSC) & $\begin{array}{l}\text { simple sample preparation, thermodynamic } \\
\text { parameter determination, liquid and solid } \\
\text { samples can be used, denaturation } \\
\text { temperatures as well as irreversible-reversible } \\
\text { phase changes can be detected }\end{array}$ & $\begin{array}{l}\text { kinetic measurements are limited to } \\
0.1-10^{\circ} \mathrm{C} / \mathrm{min} \text {, no structural information can } \\
\text { be obtained }\end{array}$ \\
\hline
\end{tabular}

determining factor [12]. Denaturation of a protein involves a change (generally unfolding) in the protein's tertiary structure such that it is no longer biologically or biochemically active. Denaturation can also occur due to chemical denaturants. The coupling of molecular mobility and denaturation kinetics has been shown to exist in high viscosity, low molecular mobility systems [13]. All of these processes may affect the stability of the proteins during preservation processes and storage, causing it to lose its activity.

In summary, the native and denatured states of a protein are composed of multiple microstates, and it is the microenvironment that dictates its structure, its intramolecular interactions, and hence its stability during preservation. There are various experimental techniques available to measure the molecular motions and to determine the structure of proteins during preservation processes and storage. Table 1 gives a brief summary of the general methods available.

\section{Current Stabilization Methods}

The state (the structure and the motions) of a protein is determined by its microenvironment. In processing and storage of proteins there are many factors that can affect its state. These are temperature, pressure, $\mathrm{pH}$, the presence of co-solutes, salts, preservatives, and surfactants [14]. Irrespective of their mode of action, all of the stabilization methods are aimed at modifying the thermodynamic state in the microenvironment of the protein. This is accomplished by either reducing the protein suspension medium by using techniques such as cooling, freezing, vitrification or by removing the medium altogether as in the case of desiccation and freeze-drying. Depending on the application and the 'value' of the product, the desired storage conditions, and the required shelf life, the method of choice differs significantly. Generally, it is almost impossible for the protein to retain its native configuration while its microenvironment is modified during any process that involves cooling, freezing and desiccation or a combination of these. Therefore, certain chemicals are added into the solution. Depending on the particular preservation method applied, these chemicals are polyols such as glycerol, sugars such as trehalose, sucrose, maltose and dextran, dimethyl sulfoxide, polyvinyl alcohol, ethylene glycol, or salts. The one most important common characteristic of all of these chemicals is that they modify the structure and the motions of the water molecules in their immediate vicinity. For example, 
Table 2. Existing commonly utilized protein stabilization methods

\begin{tabular}{|c|c|c|c|}
\hline Method & Typical process & Advantages & Disadvantages \\
\hline Diffusive or convective drying & $\begin{array}{l}\text { convective drying of solutions, } \\
\text { which contain stabilizing chemicals, } \\
\text { and the protein }\end{array}$ & $\begin{array}{l}\text { simple method, less specialized } \\
\text { equipment, economical and fast }\end{array}$ & $\begin{array}{l}\text { heterogeneity during drying, solute } \\
\text { injury possible, may lead to } \\
\text { denaturation, crystallization and } \\
\text { cracking }\end{array}$ \\
\hline Aerosol drying & $\begin{array}{l}\text { desiccation of dispersed droplets } \\
\text { by warm, dry gas stream [40] }\end{array}$ & $\begin{array}{l}\text { simple process, less specialized } \\
\text { equipment, less heterogeneity due } \\
\text { to very small sample size, fast }\end{array}$ & $\begin{array}{l}\text { atomization may be harmful to } \\
\text { sensitive proteins, aggregation and } \\
\text { denaturation at air-protein interface } \\
\text { can cause problems }\end{array}$ \\
\hline Cooling (hypothermic storage) & $\begin{array}{l}\text { proteins are suspended in a solu- } \\
\text { tion containing preservation } \\
\text { agents and cooled to } 0 \text { to }-10{ }^{\circ} \mathrm{C}\end{array}$ & $\begin{array}{l}\text { simple process, no solute or freeze- } \\
\text { thaw damage }\end{array}$ & $\begin{array}{l}\text { limited storage time, sample in liquid } \\
\text { form, prone to crystallization }\end{array}$ \\
\hline Freezing or cryopreservation & $\begin{array}{l}\text { proteins are suspended in a solu- } \\
\text { tion containing preservation agents } \\
\text { and frozen to }-20 \text { to }-190{ }^{\circ} \mathrm{C}\end{array}$ & $\begin{array}{l}\text { simple process, extensively studied, } \\
\text { relatively cheap preservation (but } \\
\text { not storage) conditions }\end{array}$ & $\begin{array}{l}\text { requires continuous low temperature } \\
\text { refrigeration and storage. requires } \\
\text { removal of cryoprotective agents } \\
\text { after thawing, re-crystallization } \\
\text { during thawing is a problem }\end{array}$ \\
\hline Freeze-drying (lyophilization) & $\begin{array}{l}\text { freezing of samples, followed by } \\
\text { sublimation and desorption [41] }\end{array}$ & $\begin{array}{l}\text { long storage time, room temperature } \\
\text { storage possible }\end{array}$ & $\begin{array}{l}\text { separation of constituents into } \\
\text { different phases [42], requires } \\
\text { expensive equipment and processes, } \\
\text { combined freezing and drying stress } \\
\text { makes is unfeasible for most proteins }\end{array}$ \\
\hline Low temperature vitrification & $\begin{array}{l}\text { high concentrations of polyol or } \\
\text { sugar based biopreservation } \\
\text { solutions are rapidly cooled }\end{array}$ & $\begin{array}{l}\text { eliminates ice crystallization-related } \\
\text { damage, stable at relatively high } \\
\text { temperatures }\end{array}$ & $\begin{array}{l}\text { requires very high concentrations of } \\
\text { preservation agents, sample is } \\
\text { heterogeneous, requires removal of } \\
\text { protective agents after rewarming }\end{array}$ \\
\hline Crystallization & $\begin{array}{l}\text { proteins solutions are crystallized } \\
\text { by centrifugation, drying or freeze- } \\
\text { concentration }\end{array}$ & $\begin{array}{l}\text { eliminates impurities, very stable at } \\
\text { low temperatures }\end{array}$ & $\begin{array}{l}\text { expensive to produce, vulnerable to } \\
\text { humidity fluctuations, not all proteins } \\
\text { can be crystallized especially in a } \\
\text { pure form }\end{array}$ \\
\hline Foam vitrification & $\begin{array}{l}\text { very thin films containing the } \\
\text { protein and biopreservation agents } \\
\text { are rapidly dried or freeze-dried }\end{array}$ & $\begin{array}{l}\text { room temperature stabilization } \\
\text { possible }\end{array}$ & $\begin{array}{l}\text { not available in commercial scales, } \\
\text { the thin films are fragile, feasibility } \\
\text { studies are not complete }\end{array}$ \\
\hline
\end{tabular}

chemical reaction rates have been shown to decrease in the presence of high concentrations of sugars, facilitating protein dynamics studies $[15,16]$, slowing down oxygen diffusion and therefore increasing the stability of fluorescent molecules [15], and reducing degradation of enzymes $[17,18]$ and proteins $[16,19]$.

There are two hypotheses commonly employed to describe the chemicals' mechanisms of action by which the molecular motions and the structures of the proteins are affected. These are i) the 'water replacement hypothesis' [20], offered as an explanation for the protective action of certain carbohydrates against freezing and desiccation damage, which predicts that the stabilization agents replace the water molecules that are removed form the hydration shells of the proteins, therefore stabilizing the protein in its native state; and ii) the "preferential exclusion' hypothesis which states that the protective agents are excluded from the macromolecule surfaces [21, 22] and thus the available water in the solution can preferentially interact with the protein, stabilizing it in its native configuration. Irrespective of the exact mechanism of protection offered, it is well-established that the microenvironment of the protein is modified, and this is reflected in the physical, thermodynamic and chemical properties of the surrounding solution.

From a thermodynamic perspective, presence of the osmolytes modify the microenvironment of the protein by altering its Gibbs free energy of denaturation (eqn. 1) [23-25]. The effect of the osmolytes on the Gibbs free energy can be analyzed through the mechanism of preferential interaction or exclusion. A comparison of different co-solutes and their 'stabilization potential' (their preferential interaction parameter [23]) can be done by calculating the change in the free energy of denaturation of the protein $(\partial \Delta \mathrm{G})$ in water with respect to that in the solution in the presence of the co-solute [24] in terms of its chemical potential $\left(\mu_{\mathrm{p}}\right)$ given by [24]:

$$
\partial \Delta \mathrm{G}=\partial \Delta \mu_{\mathrm{p}}
$$


where the change in the chemical potential of the protein is related to the preferential interaction parameter $\left(\Gamma_{\mathrm{px}}\right)[8]$

$$
\frac{\partial \mu_{\mathrm{p}}}{\partial \mu_{\mathrm{x}}}=-\Gamma_{\mathrm{px}}
$$

The subscripts $\mathrm{p}$ and $\mathrm{x}$ in eqn. 3 refer to the protein and the osmolyte, respectively. In the presence of stabilizing osmolytes the change in the free energy of denaturation is positive.

Most common preservation processes applied to stabilize proteins are summarized in table 2 , with their advantages and disadvantages. The main challenges facing stabilization of proteins are:

- Biostabilization is, in its current state, more of an art than science and still requires product-specific biopreservation methods, processes, protocols to be developed. This generally involves trial-and-error-based approaches for biostabilization formulation development. The advances in medicine and biotechnology have increased the demand for safe, efficient, dependable, and economical preservation technologies for biological materials and organisms at an unprecedented rate, and in its current state biopreservation research cannot meet the demand. For example, the problems associated with the transport of cryopreserved stem cells were very recently acknowledged as one of the major issues affecting the widespread use, safety and efficacy of cell-based therapies [26].

- With safety, energy, health, and the environment issues becoming more pronounced, the utilization of chemicals in preservation processes that are not environmentally friendly or outright harmful is becoming more of an issue. Most of the cryoprotectants are extremely cytotoxic (even mutagenic) at high temperatures (such as the widely used cryoprotectant, dimethyl sulfoxide) and therefore require removal immediately after thawing [27]. This not only adds a critical procedure to be performed before the product can be used but also residual cryoprotectant left in the product causes loss of viability, and function.

- Traditional preservation technologies such as cryopreservation, vitrification, or lyophilization require cryogenic processing or storage conditions. Sustaining the cold-chain during processing, transportation, storage, distribution, and on-site stocking presents major capital investment and very tight quality control. The Grand Challenges in Global Health Consortium declared that 'development of a method for the stabilization of vaccines that do not require cold storage' is one of the 14 major health challenges they target in this decade. The recent hurricane disaster in the Gulf Region of the USA has proven once more how important it is to develop alternative storage methods, especially for food and medicine that do not require uninterrupted refrigeration and freezing.

\section{Future of Biostabilization}

Recently, a newly developed technique for stabilization of proteins and enzymes based on nanoencapsulation procedures has started to gain momentum. This technique is based on encapsulation of macromolecules in a nanoporous matrix by the gelation of a solution (such as the sol-gel transition of $\mathrm{SiO}_{2}$ ) [28]. Due to being entrapped in a very confined environment (i.e. in the nanopores), the molecular motions of water molecules are altered. This is mainly due to the dipolar nature of water which causes it to slow its molecular motions affected by its immediate environment [29]. Therefore, confinement in nanoporous matrices (or coatings) has the same effect as the osmolytes with respect to changing the water activity and therefore modifying the biochemical reaction rates. In this environment, the motions of water are so much restricted that it does not even crystallize at temperatures as low as $-190{ }^{\circ} \mathrm{C}$ but transitions into a very viscous state, stabilizing the proteins [30]. The glass transition temperatures [31,32] and the crystallization rates of solutions are also affected by confinement. Due to increased viscosity and entropic confinement (physical entrapment), the reaction rates are slowed down, and the biological materials can be stabilized for storage. Long-term room temperature stabilization by confinement in sol-gel matrices has been possible for certain proteins and enzymes [for reviews see 33-35]. Interestingly, confined enzymes also remained reactive for longer periods of time even at increased activity rates when compared to those in suspension [36]. The advantages of nanoconfinement can be summarized as localization, increased reactivity, increased thermal and chemical resistance, ease of application, manufacturing and shaping, potential for room temperature stabilization, and elimination of purification steps. Further advances in this field will not only enable stabilization of proteins but also enable their incorporation into bioreactive coatings, biosensors, and biocatalysts. The development of certain technologies, e.g. volumetric rapid cooling, utilization of non-toxic and environmentally friendly stabilization agents, efficient, and safe preservation agent loading, and removal methods [27], without any doubt, will affect the stabilization field in a positive direction. Developments in the spectroscopic and molecular microscopy techniques will help us understand the mechanisms at the molecular level and predict the macroscopic outcome. Enhanced understanding of the mechanisms of damage at the molecular level combined with theoretical analyses will help establish the scientific basis of biostabilization field.

\section{Acknowledgements}

This research is partially supported by a grant (GIA-20328) from the Office of the Dean of the Graduate School of the University of Minnesota. 


\section{References}

1 Kanias T, Acker JP: Mammalian cell desiccation: facing the challenges. Cell Preserv Technol 2006;4 253-277.

2 Brekke OH, Sandlie I: Therapeutic antibodies for human diseases at the dawn of the twenty-first century. Nat Rev Drug Discov 2003;2:52-62.

3 Aksan A, Toner M: Roles of thermodynamic state and molecular mobility in biopreservation; in Bronzino JD (ed): The Biomedical Engineering Handbook. Boca Raton, Taylor and Francis, 2006, vol 3, pp 41-1-41-20.

4 Kreilgaard L, Frokjaer S, Flink JM, Randolph TW, Carpenter JF: Effects of additives on the stability of recombinant human factor XIII during freeze-drying and storage in the dried solid. Arch Biochem Biophys 1998;360:121-134.

$\checkmark 5$ Crowe JH, Tablin F, Wolkers WF, Gousset K, Tsvetkova NM, Ricker J: Stabilization of membranes in human platelets freeze-dried with trehalose. Chem Phys Lipids 2003;122:41-52.

6 Fenimore PW, Frauenfelder H, McMahon BH, Parak FG: Slaving: solvent fluctuations dominate protein dynamics and functions. Proc Natl Acad Sci U S A 2002;99:16047-16051.

7 Kurzynski M: The Thermodynamic Machinery of Life. New York, Springer, 2006.

8 Scharnagl C, Reif M, Friedrich J: Stability of proteins: temperature, pressure and the role of the solvent. Biochim Biophys Acta 2005;1749:187-213.

$\checkmark 9$ Zhou D, Zhang GGZ, Law D, Grant DJW, Schmitt EA: Physical stability of amorphous pharmaceuticals: Importance of configurational thermodynamic quantities and molecular mobility. J Pharm Sci 2002;91:1863-1872.

10 Fawzi NL, Chubukov V, Clark LA, Brown S, HeadGordon T: Influence of denatured and intermediate states of folding on protein aggregation. Protein Sci 2005;14:993-1003.

11 Duddu SP, Zhang G, Dal Monte PR: The relationship between protein aggregation and molecular mobility below the glass transition temperature of lyophilized formulations containing a monoclona antibody. Pharm Res 1997;14:596-600.

12 Shamblin SL, Hancock BC, Pikal MJ: Coupling between chemical reactivity and structural relaxation in pharmaceutical glasses. Pharm Res 2006;23 2254-2268.

13 Tang X, Pikal MJ: Measurement of the kinetics of protein unfolding in viscous systems and implications for protein stability in freeze-drying. Pharm Res 2005;22:1176-1185.
14 Chi EY, Krishnan S, Randolph TW, Carpenter JF: Physical stability of proteins in aqueous solution: mechanism and driving forces in nonnative protein aggregation. Pharm Res 2003;20:1325-1336.

15 Mei E, Tang J, Vanderkooi JM, Hochstrasser RM: Motions of single molecules and proteins in trehalose glass. J Am Chem Soc 2003;125:2730-2735.

16 Sastry GM, Agmon N: Trehalose prevents myoglobin collapse and preserves its internal mobility. Biochemistry 1997:36:7097-7108.

17 DePaz RA, Dale DA, Barnett CC, Carpenter JF, Gaertner AL, Randolph TW: Effects of drying methods and additives on the structure, function and storage stability of subtilisin: role of protein conformation and molecular mobility. Enzyme Microb Technol 2002;31:765-774

18 Miller DP, Anderson RE, de Pablo JJ: Stabilization of lactate dehydrogenase following freeze-thawing and vacuum-drying in the presence of trehalose and borate. Pharm Res 1998;15:1215-1221.

19 Allison SD, Chang BS, Randolph TW, Carpenter JF: Hydrogen bonding between sugar and protein is responsible for inhibition of dehydration-induced protein folding. Arch Biochem Biophys 1999;223 289-298.

20 Webb SJ: Bound Water in Biological Activity Springfield, Charles C. Thomas, 1965.

21 Xie G, Timasheff SN: Mechanism of the stabilization of ribonuclease a by sorbitol: preferential hy dration is greater for the denatured than for the native protein. Protein Sci 1997;6:211-221.

22 Arakawa T, Timasheff SN: Stabilization of protein structure by sugars. Biochemistry 1982;21:65366544.

23 Arakawa T, Timasheff SN: Preferential interactions of proteins with salts in concentrated solutions. Biochemistry 1982;21:6545-6552.

24 Xie GF, Timasheff SN: The thermodynamic mechanism of protein stabilization by trehalose. Biophys Chem 1997;64:25-43.

25 Street TO, Bolen DW, Rose GD: A molecular mechanism for osmolyte-induced protein stability. Prc Natl Acad Sci U S A 2006;103:13997-14002.

26 Preti RA: Bringing safe and effective cell therapies to the bedside. Nat Biotechnol 2005;23:801-804.

27 Fleming KK, Hubel A: Cryopreservation of hematopoietic stem cells: emerging science, technology and issues. Transfus Med Hemother 2007;34(4): 268-275
28 Ferrer ML, Yuste L, Rojo F, del Monte F: Biocompatible sol-gel route for encapsulation of living bacteria in organically modified silica matrixes. Chem Mater 2003;15:3614-3618.

29 Scheidler P, LKob W, Biner K: Cooperative motion and growing length scales in supercooled confined liquids. Europhys Lett 2002;59:701-707.

30 Flickinger MC, Schottel JL, Bond DR, Aksan A Scriven LE: Painting and printing living bacteria: engineering nanoporous biocatalytic coatings to preserve microbial viability and intensify reactivity. Biotechnol Prog 2007;23:2-17.

31 Zhang J, Liu G, Jonas J: Effects of confinement on the glass transition temperature of molecular liquids. J Phys Chem 1992;96:3478-3480.

-32 Ellison CJ, Torkelson JM: The distribution of glasstransition temperatures in nanoscopically confined glass formers. Nat Mater 2003;2:695-700.

33 Jin W, Brennan JD: Properties and applications of proteins encapsulated within sol-gel derived materials. Anal Chim Acta 2002;461:1-36.

34 Pierre AC: The sol-gel encapsulation of enzymes. Biocatal Biotransformation 2004;22:145-170.

35 Livage J, Coradin T, Roux C: Encapsulation of biomolecules in silica gels. J Phys: Condens Matter 2001;13:R673-R691.

36 Avnir D, Coradin T, Lev O, Livage J: Recent bio applications of sol-gel materials. J Mater Chem 2006;16:1013-1030.

37 Manning MC: Use of infrared spectroscopy to monitor protein structure and stability. Exp Rey Proteomics 2005;2:731-743.

38 Pelton JT, McLean LR: Spectroscopic methods for analysis of protein secondary structure. Anal Biochem 2000;277:167-176.

39 Montelione GT, Zheng D, Huang YJ, Gunsalus KC, Szyperski T: Protein NMR spectroscopy in structural genomics. Nat Struct Biol 2000;7: 982-985.

40 Maa YF, Nguyen PAT, Hsu SW: Spray-drying of air-liquid interface sensitive recombinant human growth hormone. J Pharm Sci 1998;87:152-159.

41 Roy I, Gupta MN: Freeze-drying of proteins: some emerging concerns. Biotechnol Appl Biochem 2004;39:165-177.

42 Izutsu K, Kojima S: Freeze-concentration separates proteins and polymer excipients into different amorphous phases. Pharm Res 2000;17:1316-1322. 